\title{
THE JURISPRUDENTIAL FOUNDATIONS OF IRAN'S CRIMINAL POLICY CONCERNING THE SPREAD OF PROSTITUTION COVERED IN THE 2013 PENAL CODE
}

FUNDAMENTOS JURISPRUDENCIALES DE LA POLÍTICA PENAL DE IRÁN RELACIONADOS CON LA PROPAGACIÓN DE LA PROSTITUCIÓN DEL CÓDIGO PENAL DE 2013

\author{
Ardavan Arzhang* \\ Abozar Fadakar Davarani** \\ Mohammad Nozari Ferdowsieh ${ }^{* * * *}$
}

\begin{abstract}
The legislator has acted to criminalize the field of public chastity in order to preserve public morality; one of these cases considers prostitution. Publication of some news and images, especially those that may appear today in various mass media, such as Internet websites, certainly leads to the dissemination and spread of content that contradicts public morality and ethics, that confronts ethical norms and values. That's why the publication of such information is prohibited by law. Concerning the spread of prostitution, this paper analyzes two instances of abuse, that contradict public morality and are related to each other. The main question in this paper is, what does the Iranian criminal policy do against the spread of prostitution, covered in the Islamic Penal Code approved in 2013? After an introduction (Chapter I), we analyze some jurisprudential concepts and principles related with this matter (Chapter II). In Chapter III we see some examples of the spread of prostitution in domestic law. Finally, we take care of the role of corruption in the spread of prostitution (Chapter IV) and then we resume some conclusions (Chapter V).
\end{abstract}

\footnotetext{
* Member of the Faculty of Jurisprudence and Law Department, Ayatullah Hayeri University of Meybod (Meybod, Iran). arzhang1345@gmail.com

** Student of jurisprudence and Criminal Law, Ayatollah Hayari University of Meybod (Meybod, Iran).daverani@yahoo.com

*** Member of the Faculty of Jurisprudence and Law Department at Qom University (Qom, Iran).abasaleh.s@gmail.com
} 
Keywords: Prostitution Dissemination, Criminal Policy, Corruption on Earth, Criminal Code of 2013, Public Morality

Resumen: El legislador ha legislado para criminalizar ciertas conductas en el campo de la castidad pública a fin de preservar la moralidad pública; uno de estos casos considera la prostitución. La publicación de algunas noticias e imágenes, especialmente las que pueden aparecer hoy en varios medios de comunicación, como sitios web de Internet, contradice la moral y la ética públicas, y confronta normas y valores éticos. Por eso, la publicación de tales informaciones está prohibida por la ley. Con respecto a la propagación de la prostitución, se analizan dos casos de abuso, contrarios a la moral pública, estrechamente relacionados entre sí. La pregunta principal de este trabajo es, ¿qué hace la política criminal iraní contra la propagación de la prostitución, cubierta en el Código Penal Islámico aprobado en 2013? Después de una introducción (Capítulo I), analizamos algunos conceptos y principios jurisprudenciales relacionados con esto (Capítulo II). En el Capítulo III se pasa revista de algunos ejemplos de difusión de la prostitución en la ley doméstica. Finalmente, tomamos en cuenta el rol de la corrupción en esta difusión (Capítulo IV) para dar las pertinentes conclusiones (Capítulo V).

Palabras clave: diseminación de la prostitución, política criminal, corrupción en el planeta, Código Penal de 2013, moralidad pública

Sumario. I. Introduction. II. Jurisprudential concepts and principles of the spread of prostitution. III. Examples of the spread of prostitution in domestic law. III.1. The Islamic Penal Code. - In terms of the perpetrator of the crime. - In terms of the quantity of committed crimes. - In terms of quality and intention of committing a crime. III.2. Press laws and computer crimes. IV. The role of corruption in the spread of prostitution. IV.1. The concept and basis of corruption on earth. a) The concept of "corruption". b) The concept of "on earth". IV.2. Islamic Penal Code's approach to the spread of prostitution. V. Conclusions. References.

\section{INTRODUCTION}

One of the phenomena, that have been censored to preserve the cultural, religious values and achievements of the community, is to preserve public chastity through the restriction of prostitution.

Unfortunately, despite the severity of this crime, it has not been deeply investigated. The peculiar feature of this crime is its direct influence 
on the beliefs and behaviours of society. Therefore, due to the changes in society, this crime often becomes an object, that is reconsidered. Therefore, time and place significantly influence this topic, because the values of societies are constantly changing, and the thoughts or beliefs of the society, not people, become the victims of this crime.

The scope of the violation of general offending issues concerns the spread of prostitution and vices, such as incitement, encouragement, persuasion, threat, corruption, and the commission of these crimes, which leads to the spread, distribution, and managing of the content contradictory to public chastity. This crime should be regulated by the Islamic Penal Code (Ghodsi \& Bi Niyaz, 2011, pp. 135-136).

The subject of crimes, that is against chastity and public morality is the dignity, credibility, personal and family privilege of individuals who value the society they live in and customs. That is why, this new law reminds about these values, concerning infidelity, chastity and sexual morality. Respect of the dignity of the people, who are in harmony with the logic and are socially conscious, had been obligatory. That is why any behavior that contradicts these social values has to be prosecuted and punished as a crime against chastity and general morality (Ekrami, 2010, pp. 85-88).

\section{JURISPRUDENTIAL CONCEPTS AND PRINCIPLES OF THE SPREAD OF PROSTITUTION}

The meaning of "spread" is to publish, even if it is not intended to promote or advertise. Fakhr Razi writes: «the meaning of spread is publication». It is also viewed as the spread of Hadis, when the word is being spread among people. The word "prostitution" means sin, mischief or adultery. Therefore, prostitution and prostitute mean any kind of behavior or speech, that are greatly unpleasant (Talkhabi \& Taqi Khani, 2011, pp. 88-89).

The main root of this word is obviously ugliness, and it is similar to disgrace, hymen, mischief, disgust, falsehood, criminality. However, disgust is an act against goodness, that is materially manifested: in speech, in evil inaccurate behavior, not in absolute terms. Mischief is something that is not good in its very essence, whether in the form or in any other way. Detriment and loss are against benefits and profits; it happens in an unknown place and might sometimes be even desirable. Corruption, disorder in action or vote is against the law. Exposing means revealing the badness and its evolution. Disdain against love, means something that is 
not desirable. The discovery of bad speech, the expression of grudge and fatigue, the violation of law, the deliberate and severe revenge, practice of all the concepts, that were mentioned above, is called prostitute and prostitution. Evil, denial, oppression, adultery, sin all are examples of prostitution and courtesan, but not the exact equivalents of it (Mostafavi, 1992, pp. 35-36). The Holy Qur'an, in verse 19 of the surah of Noor, explicitly condemns the spread of prostitution and has affected people, who are interested in this work.

There are two possibilities in the interpretation of this verse:

1. فى الَّذينَ آََنُوا belongs to the predetermined agent, which is the attribute "Al-Fahesheh". Therefore, the meaning of the verse is: «Those, who love that evil acts, that are among the believers (and some of them, who are infected with it) to be spread, will have a painful retribution».

2. فى الَّنينَ آَنُُو ا belongs to "Tashi", which will be the meaning of the verse: «Those who love evil deeds to be spread among believers will have a painful retribution».

Based on two probabilities, the verse of Shrifa refers to our discussion, and means dissemination of content contradictory to chastity, general ethics in the media. Although the second possibility relates to the discussion more closely (Talkhabi and Taqi Khani, 2011, pp. 89-90).

On the other hand, it has been written in narratives that disclosing the evil of the believer is included in verse 19 of the Surah Noor:

1. Mohammad ibn Fazil has quoted from Hazrat Mosa ibn Ja'far (let him rest in peace): «I said to Imam, I'm yours».

There is news from a man of my brothers that I'm not happy about. I ask him, he denies, while the news carriers are trusted and trustworthy people. The Hazrat said:

«O Mohammad, deny the hearing and take care of your brother, even if 50 people have testified against him. If he says I have not said, understand him and reject the words of those fifty people and do not spread anything against him to spoil him and ruin his personality, and you will be among the people, to whom God would say: "Those people who love to spread the bad among the people of the faith, in this world and the Hereafter, will be in a painful torment».

2. Anyone who tells something about the believer what he has seen with his two eyes and heard with his two ears, is one of those people, about whom Allah had said: «Those who love to spread the bad work among the people of the Faith, will be in a painful torment in this world and the Hereafter, because of their words».

3. Anyone who says about a believer who has not seen or heard is one of the people, about whom God had said: «Those who love to spread 
and repent the bad among the people of the faith, in this world and the Hereafter, will be in a painful torment».

Everyone who tells about a believer what he has seen with his two eyes and heard with his two sons is one of the people, about whom Allah had said: «Those who love to spread the bad among the people of the Faith, in this world and the Hereafter, will be in a painful torment for their words».

4. Anyone who says about a believer who has not seen or heard is one of the people, about whom God had said: «Those who love to spread and repent the bad among the people of the faith, in this Hereafter and the world; it will be a painful retribution».

These two narratives include the one who inspects the secrets of the believer, and he spreads the things he wanted to conceal by purpose (Talkhabi \& Taqi Khani, 2011, pp. 90-91).

It is clear from all the Islamic narrations and their interpretations, that disclosure of certain private matters is not permissible even with the consent of the owner of the privacy, as it is viewed as the spread of prostitution. It is also the disclosure of what is related to human sexual issues, because maintaining the private part of body is obligatory.

\section{EXAMPLES OF THE SPREAD OF PROSTITUTION IN DOMESTIC LAW}

The laws have also been set for the disclosure of prostitution. If such crime is committed, there will be punishment for them. About those laws we can include:

\section{III.1. The Islamic Penal Code}

This Code has tried to refer to the examples of this crime and punishments for it in several articles; in fact, as mentioned below, this type of crime has been divided into two categories of Hodod and also Tazir, and with the realization of the verdict can even result in the death penalty.

«Everyone who commits crimes against the physical integrity of individuals, crimes against the internal or external security of a country, publishing librations, disrupting the country's economic system, bursting and destroying, distributing poisonous and microbial and hazardous toxic substances, or setting up corrupt and prostitution centers or assists in them, that leads to severe disruption of the general order of the country, insecurity or major damage of the physical integrity of individuals or public and private property, spreads corruption or prostitution to a large extent is viewed as a corruptor and is sentenced to execution» (Islamic Penal Code 2013, Art. 286). 
It is stipulated in the note to the same article:

«Whenever the court does not acquiesce from the sum of evidence and causes the intention of widespread distortion in public order, the creation of insecurity, major damage, the spread of corruption or prostitution to a large extent, or the knowledge of the effectiveness of the conducted measures and the committed crime is not subject of any legal penalty; according to the extent of the harmful consequences of the offense, he or she is sentenced to five or six degrees of discretionary (Tazziri) imprisonment».

According to the contents of the titles used in Art. 286 of the new Penal Code of 2013, the features or coordinates of the crime of corruption on earth can be understood as follows:

\section{- In terms of the perpetrator of the crime}

The use of the title "Everyone" in the first paragraph of this article indicates that the offender, who has committed an offense, should include all people, whether male or female or non-Muslim, who have the general conditions of the duty, whether they are young, or old and who commit this crime on the territory of the country (Validi, 2014, p. 403).

\section{- In terms of the quantity of committed crimes}

The scientific and literary works of the usage of the mentioned word, at the beginning of this article states $«(. .$.$) commit the crimes against the$ physical integrity of individuals, crimes against domestic or foreign security, the spread of false rumors (...)», this means that in the view of the legislator, the commission of one case of the offenses mentioned in this article, such as intentional murder, cannot be compared with a crime of corruption (Validi, 2014, p. 403).

\section{- In terms of quality and intention of committing a crime}

There is no doubt that the usage of the sentence «(...) in a manner that disturbs the public order of the country, causes insecurity or major damage to the physical integrity of individuals or public and private property, or causes the spread of corruption or prostitution to a large extent» shows the criminal intention to obtain one of the mentioned results in this article and is a fundamental and essential condition for the crime to be committed. In addition to this analysis, this article declares:

«The court has to carefully examine the variety of evidence and causes, intentions to distort the general order, create insecurity, create major damage, or 
spread of corruption or prostitution to a large extent, or the knowledge of the effectiveness of the conducted measures (...)» (Islamic Penal Code 2013, Art. 286).

Another clear proof of that this can be viewed as crime is the consequences of the emergence of corruption on the earth (Validi, 2014, p. 404).

\section{III.2. Press laws and computer crimes}

In the two mentioned laws, in light of the importance of the issue, especially in the traditional and new media, such as the Internet, the legislator has tried to point out some cases of the spread of prostitution and acts against the public chastity that it includes the following cases:

Art. 6 of the press law limits the scope and freedom of expression in the press have been considered by the legislature; it should be explained that according to the exact phrase of the article «except in cases of disturbance to Islamic principles and rules and public and private rights (...)». It can be said that the principle is based on the limitation unless the cases and examples referred to in this article are observed.

Therefore, journals are free except for breaking the principles, rules of Islam and the public and private rights that are specified in this chapter:

- Propaganda of prostitution and the spread of photographs and images and contents contradictory to public chastity.

- The usage of those photos without the allowance of individuals (including men and women), who are the images and contents, humiliation and insulting the sex of women, propagation of illegitimate and illegal forms and designs, the drafting of the contents cause to contribute to the conflict between men and women through non-legal defense of their rights.

It has been noted in the note of the same Art. 6 of the press law, that «the violations of the provisions of this article shall be the subject of the penalties provided in Art. 698 of the Islamic Penal Code, and, in the event of insistence, entails the intensification of the punishment and the cancellation of the permission».

On the other hand, due to the importance of the issue in the mentioned law, it is emphasized that the spread of photographs and images and contents contradictory to the public chastity is prohibited and causes legal denunciation, and its insistence will intensify the punishment and cancellation of the license, as well as the spread of contents, that include the thread to honesty or dignity violation or disclosure of personal secrets is prohibited, and the responsible manager will be introduced to the court of law and will be treated in accordance with the law of ta'zirat. 
But in the computer crime law, the legislator also has referred to this crime in chapters four and five. With this explanation that anyone who produces, sends, publishes, distributes or trades that unlawful contents by a computer or telecommunication systems or produces, stores, maintains content will be sentenced to imprisonment from one day to two years, or a fine of five to forty million rials, or both punishments. As well as anyone who commits the following acts through computer or telecommunication systems or data carriers, will be punished in the following order:

a) In the event of inciting, persuading, threatening or deceiving, or threatening them in order to make easy the way to access them, or training them, will be sentenced to imprisonment from ninety-one days to one year; or A fine of five to twenty million rials, or both of them. The commission of these acts regarding vulgar content causes a fine of two to five million rials.

b) In the case that incite or invite persons to commit crimes against of commotion or use of narcotic or psychotropic drugs, suicides, sexual deviations, acts of violence, or to deceive or suppress the manner of committing, using them, train them, will be sentenced to imprisonment from ninety-one day to one year, or a fine of five to twenty million rials, or both of them.

c) Note: the materials of this article and Art. 14 shall not include those contents which are produced, stored, presented, spread, traded for scientific or any other rational purpose (Press laws and computer crimes, Art. 15).

But the legislator has disregarded the dignity under the propaganda of prostitution, and has stipulated that any person, who changes, distorts and distributes by means of computer or telecommunication systems, films or sound, pictures of other person with the knowledge of alteration or distortion, in a way that will disrupt his/her dignity, will be sentenced to imprisonment from one day to two years or a fine of five to four hundred million rials, or both.

Altogether, according to the legal provisions, it can be said that the prevalence of computer crimes in various social areas causes various damage and losses in the society. One of the most important damages to person and society had been the elimination of the ethical principles and social system, which causes great damages to the economic, political and cultural systems of the society. Computer technologies are constantly developing; computer-related criminal offences involving unethical hacking will also be developed and will have a negative effect on the social and fundamental system of families.

After reviewing the existing computer crime laws, it seems that the laws, that can deal with these crimes, are minimal and they regulate only the today's need. Therefore, with the advancement of this technology, it is necessary to think that moral and legal studies with this regard will also be 
expanded, and governments should align their laws with computer crimes. What has to be done with the ethical, social, and legal considerations of computer crime is that it is necessary to emphasize on the understanding of the main legal and ethical issues of citizens in the virtual space and claim that protection of the intellectual rights of computer software creators or intellectual property rights, promotion of health information, confidence building in cyberspace, creation of an undeniable principle and prevention of unauthorized release of text, audio, video, pornography in cyberspace are important. Data and network security are cases that need to be implemented in the cyber environment in order to guarantee human and religious ethics concerning the social order and the psychological influence on people, society and sovereignty.

\section{THE ROLE OF CORRUPTION IN THE SPREAD OF PROSTITUTION}

Among the criminal titles that are used in Islamic jurisprudence and, as a consequence, in the Penal Code of the present case, which results in the spread of prohibited and Haram act in society, is corruption on earth. After the 1979 revolution, the title of "corruption on the earth" came to the forefront of Islamic law with the idea of making Islamic criminal laws, but from the very beginning, due to the non-observance of some features of criminal laws, political considerations, and the neglection of criminal concepts, that should have the clear definition, in order to better understand the subject and create a clear picture of the problem, the titles and related terms are investigated while providing the root meanings of the concept "corruption on the earth" and the major definitions of jurists and jurisconsult.

\section{IV.1. The concept and basis of corruption on earth}

Taking into account the fact that every word has its own meaning and the idiomatic meaning is borrower from the same lexical meaning, the meaning of the word "corruption" and its constraint "on the earth" is investigated (Nana Kar, 1998, p. 32), then the definitions of the term jurists and lawyers will be studied.

a) The concept of "corruption"

The term "corruption" means destruction, destroying, disintegration, and is also defined as destruction, sedition, badness and evil in the 
dictionary of Moein (1985, the appendix of corruption word). In Amid dictionary, "corruption" also means destruction, destroying, disintegration, ruin, destruction, sedition and chaos (Amid, 1996, the appendix of corruption word). It has been brought in another part, that corruption from the root of "Fasada, Yafsada, Afsad, Fasadan" has been interpreted as counter-correcting actions, meaning "getting out of moderation limit and disrupting the order of everything" (Mousavi Bojnourdi, 1988, p. 205).

It has been brought in the Tabieno Al-Loghat, "Fasad, Yafsada, Fasadan and Fasodan" means «destruction and getting out of the moderation limit that has been used both in the soul and in the body as well as in things that have been out of endurance, and is counter-intuitive (...)» (Gharib, 1987, p. 238). The word "corruption" itself also has another meaning, such as starting and defaming, and obtaining money from corruption and adultery, and it has been stated in the philosophical definition that «it means the destruction of the form of matter that it has been created after it» (Ragheb Esfahani, 1995, p. 633).

From the study of the Qamos Quran, it appears that the term "corruption" has been mentioned on six facets in the Holy Qur'an (Habibzadeh, 2000, p. 146): (i) disobedience; (ii) destruction and bloodshed; (iii) shortage of rain and shortage of cereals; (iv) slaughter; (v) creating a failure to cruelty and abuse; and, (vi) witchcraft.

From what has been said before, it can be concluded that the term corruption and all derivatives of it in Persian and Arabic, or both jurisprudential and philosophical, and in a comprehensive way means to get out of moderation and to disrupt the moderation and order of anything and corruptionist is someone who causes the collapse of the order and moderation of objects (Nana Kar, 1998, p. 36).

So, with regard to the usage of the word "corruption", especially in the Arabic culture and literature, it can be said that the concept of corruption and sanity is universal, and everyone who acts righteously is competent, that if he benefits from others, who are good people or anyone, who has committed the corruption and harms others, is corrupt and corrupted person respectively.

\section{b) The concept of "on earth"}

Regarding the lexical meaning of corruption, undoubtedly any crime and sin that comes from mankind, is considered as a corruption in one aspect of his life, but here the title of corruption has been added to "on the earth", it means that its meaning is bounded with the corruption that is 
committed on the earth. The term "land" in the "Mofradat of Ragheb Esfahani" is defined as:

«The lower and the upper of everything have been interpreted into the same earth, as everything, that is called Sama is above. The term "earth" is any phenomenon that returns to life after erosion, and after creation returns to life and growth (...)» (Ragheb Esfahani, 1995, p. 73).

There are three possibilities to quell corruption in the earth:

The first possibility is to state the cornerstone of corruption, that is, corruption is done on earth, so this covers all the mistakes that occur on the earth.

The second possibility - the belief in corruption on the basis of the "on the earth" implies in this meaning that «corruption is done on the earth, and the earth becomes corrupt».

Accordingly, corruption on earth means to ruin the earth, but not in the sense that the essence of the earth is destroyed, but in the sense that the state of the term and the good form of earth is ruined (Hashemi Shahroodi, 1999, pp. 236-237).

But now the question comes to mind which of these probabilities can be correct? It should be said about the first possibility, that since a person, who is not a subject of the crime on the earth, should not be affected by the punishment and penalty, then, in fact, it is a kind of exception of the phrase "on the earth", but it is not a dominating word.

But about the second possibility, according to some scholars, considering that a minor and not common crime may also be called "corruption on earth", such as the handing over of one person to two or more people, which this corruption on the earth, although it is a personal crime and has been committed by one person, is subject to the verse and corruption on earth, but it cannot be the subject of an outbreak of corruption (Hashemi Shahroodi, 1999, p. 237).

In this comment, it should be said that if the purpose is a public outbreak and to be obviously a crime of corruption and is to be considered as a security impediment, this perception could be correct.

In the case of the third possibility, since the land has been considered because it is the place of residence and location of the human beings and the land is also desirable for humankind, the life of whom depends on the existence of the earth. Hence, the goodness of the earth is that it to be suitable for human life, that it is interpreted: "corruption is on the earth", not "corruption of earth", which itself implies that the actions of corruptors or enmities, and to be in the same state of destruction on earth and corruption, and corrupts the essence of the earth. Therefore, the 
interpretation of corruption on earth indicates that it is important that "corruption" exists on the ground and its jurisdiction for the deployment of human beings disappears (Hashemi Shahroodi, 1999, p. 237).

Here, according to the verses of the Holy Qur'an, who in some cases refers to the word "earth" to the whole world, in some cases, also each city

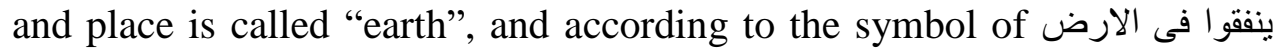
are followed by the verse انما جزاء الذين, which, according to some commentators and scholars, is the phrase يسعون فى الارض فسادا on the Islamic territories (Mohaghegh, 1985, p. 375).

The third possibility seems to be worth the point that corruption in the Islamic territories is flowing and its jurisdiction for human and security disappears.

As mentioned, the characteristics of this crime are due to the type of society's reaction to the perpetrator of the crime of corruption on earth because according to Art. 286, the punishment of corruptor on earth is the death penalty that the legislator explicitly has predicted in this article.

\section{IV.2. Islamic Penal Code's approach to the spread of prostitution}

One of the new approaches to the Islamic Penal Code, adopted in 2013, regarding the Islamic Penal Code approved in 1991, is the addition of a note to the crime of corruption on earth in Art. 286 of the mentioned Act, according to it, whenever the court, does not understand from the sum of evidence and causes, intention to extensive disrupt in public order, create insecurity, major damage, or the spread of prostitution to a large extent, or knowledge of the effectiveness of the measures taken, and the offense of commission is not subject to other legal penalties, the person will be sentenced to the imprisonment of the fifth or sixth degree depending on the extent of the harmful consequences of the crime.

On the other hand, it should be noted that «the issuance of sentence and the execution of penalties» for the following crimes are not suspendable:

a) Crimes against internal and external security of the country, vandalism in water, electricity, gas, oil and telecommunications facilities.

b) Organized offences, armed robbery or assault, kidnapping and spamming.

c) Showing the power and harassment with a knife or any other weapon, crimes against public chastity, the establishment or operation of centers for corruption and prostitution. «Therefore, the practice of prostitution cannot be postponed or suspended» (Islamic Penal Code 2013, Art. 286). 


\section{CONCLUSIONS}

1. According to the fourth principle of the Constitution, all civil, criminal, financial, economic, administrative, cultural, military, political laws and regulations, are the cases that should be based on Islamic principles, and also the judge is required to try to find the ruling in any lawsuit and if he does not, on the basis of credible Islamic sources, issue a decree issued by the competent Fatwa, and cannot refrain from considering and contesting the judgment under the pretext of silence or imperfection or controversy or conflict of laws, then virtually all the laws and the rules must be in accordance with the rules of jurisprudence, and therefore Iran's criminal policy should be in line with it.

The legislator has not defined the definition of "crimes against chastity" and "spread of prostitution", in the mentioned law and has not even provided a specific legal standard, so that crimes against chastity can be recognized. As a result, the overall elements of this type of crime are unclear. The legislator, instead of defining crimes of chastity to determine its consequences, has calculated the examples to determine its definition. The legislator has acted to do criminalization in the field of public chastity. In order to preserve public chastity and public morality, without defining the titles such as the spread of prostitution, and since the most severe way of behavior of the government with the actions and behaviors of individuals appears through the adoption of criminal laws and regulations and thus a part of individual freedoms are limited by deliberate acts of the government, there must be criteria and standards for the concept of public chastity and the criminalization of acts of deprivation of public purity, in order to prevent from illegal invasion of people's freedoms by legitimizing the usage of criminal proceedings on the part of the government.

2. In addition, in order to avoid overlapping of morality and law, the guarantee of these criminal acts should be limited to acts that are contradictory to the general chastity in its narrow sense.

3. On the other hand, acts of public chastity, have been included both in the section of Hudud (limits) and as well as in the section of sanctions. Considering that the crimes, that requires the Hudud, are the crimes which the quality and ways of committing, it has been predicted from the Holy lawgiver (God and prophet), therefore, for this purpose that the perpetrator has to be the subject of the ruling of the relevant articles, the commission of the offense must be in conformity with the legal requirements of its fulfillment.

4. Regarding acts contrary to public virtue, such as dissemination of Prostitution sentenced of Ta'zir due to the fact that the legislator has not 
provided a specific legal standard for the identification of instances of acts contrary to public morals the judges can issue the sentence and punishment.

Hence, there will be problems, including the violation of the principle of the legality of the crime and punishment by the judicial authorities and the defendants of the judiciary, and this important necessitates, the expression of instances, particular elements of the acts against the public chastity to induce ta'zir, hereby, can prevent from a series of illegal encounters in the area of general chastity, which can lead to the results, such as the rise criminal inflation about sexual issues and dissemination of prostitution, because in Islamic holy religion, emphasis has been placed on concealment and repression.

\section{REFERENCES}

Amid, H. (1996). Amid Dictionary, $1^{\text {th }}$ vol. Tehran: Amir Kabir.

Ekrami, J. (2010). Crimes against Chastity and Public Ethics. Journal of Legal Discourse, 17-18, pp. 73-94.

Gharib, M. (1987). Tabin Al-Loghat Al-Tabayan Al-Ayat, vol. 2. Tehran: Bonyad.

Ghodsi, E. \& Biniyaz, M. (2011). Audio and Visual Criminality in the Realm of Chastity and General Ethics. Jurisprudence and Islamic Law Studies, 3(4), pp. 135-176.

Habibzadeh, M.J. (2000). Moharebeh in Iran's Criminal Law. Tehran: Tarbiat Modares University.

Hashemi Shahroodi, S. M. (1999). The requirements of Criminal jurisprudence. Tehran: Mizan.

Moein, M. (1985). Moein Dictionary, $2^{\text {nd }}$ edition. Tehran: Amir Kabir Publishing.

Mohaghegh, M. B. (1985). Daerar al-Gharaed, volume1. $2^{\text {nd }}$ edition. Tehran: Beast.

Mostafavi, H. (1992). Al-Tahghigh Fi Kalamat al-Quran al-Karim, $9^{\text {th }}$ vol. Tehran: Mostafavi Publication.

Mousavi Bojnourdi, M.K. (1988). Great Islamic Encyclopedia. Tehran: GIE.

Nana Kar, M. (1998). Corruption on the earth in jurisprudence and jurisprudence. Mursal Publication: Tehran.

Ragheb Esfahani, H. (1995). Mofradat al-faz al-Quran. Tehran: Dar al-Ghalam publisher.

Talkhabi, M. \& Taqi Khani, A. (2011). The jurisprudential analysis of the problem of dissemination of prostitution and its adaptation to media activities. Journal of Jurisprudence and Communications Law, 1, pp. 87-106.

Validi, M.S. (2014). A Describe the Requirements of the Islamic Penal Code Compared to and Complied with the Existing Law, $3^{\text {th }}$ ed. Tehran: Jangal Publishing. 